\title{
How Quickly They Forgot: Ivan IV in Muscovite Historical Memory
}

\author{
Ch. J. Halperin
}

For citation: Halperin Ch. J. How Quickly They Forgot: Ivan IV in Muscovite Historical Memory. Vestnik of Saint Petersburg University. History, 2018, vol. 63, issue 1, pp. 223-243. https://doi. org/10.21638/11701/spbu02.2018.115

This article deals with the history and historical memory of medieval Russia. Because sources written after the death of Ivan the Terrible (1533-1584) figure prominently in historical studies of his life and times, the accuracy of information about him in Muscovite historical memory is a vital concern. Meanwhile, no one has systematically posed this question as far the corpus of relevant sources as a whole is concerned. A comprehensive survey reveals that late sixteenth- and seventeenth-century Muscovite texts contain a significant number of historical errors. This article discusses the extent to which errors in later sources reflect ignorance of sixteenth-century Russian history. Authorial ignorance of Ivan's reign must be taken into account in evaluating these sources. The author draws the conclusion that ignorance of Ivan's reign in Muscovite historical memory was far greater than has been appreciated. This situation may be connected with a common feature of Russian culture: Muscovy remained a manuscript culture at this time. But the author draws another conclusion: this ignorance was probably not a product of Muscovy's failure to join the Print Revolution. The virtual absence of print technology in Muscovy might not have been the cause of ignorance of the reign of Ivan Groznyi in Muscovite historical memory. The author "tentatively" formulated the following five observations: the transition to print was a process, not a rapid "revolutionary" change; typographical errors replaced scribal errors; bias, both dynastic and religious, dominated interpretations even in relatively accurate histories; Printing did nothing to eliminate ancient myths and legends in historiography; although printing could generate myths and legends about more recent rulers, it is possible that printed histories avoided the most fantastic myths and legends about more recent history. Historical memory is always selective, and errors of omission are just as erroneous as errors of commission.

Keywords: Ivan the Terrible, Muscovy, historical memory, printed books, manuscript sources.

\section{Как быстро они забыли: Иван IV в московской исторической памяти}

\section{Ч. Дж. Гальперин}

Для цитирования: Halperin Ch. J. How Quickly They Forgot: Ivan IV in Muscovite Historical Memory // Вестник Санкт-Петербургского университета. История. 2018. Т. 63. Вып. 1. С. 223-243. https://doi.org/10.21638/11701/spbu02.2018.115

Статья посвящена истории и исторической памяти средневековой России эпохи Ивана Грозного (1533-1584). Источники о жизни и деятельности царя, появившиеся после его смерти, широко используются в исторических исследованиях, что достаточно остро

Halperin Charles J. - PhD, Bloomington, Indiana, USA; chalperi@indiana.edu Гальперин Чарльз Дж. - PhD, США, Индиана, Блумингтон; chalperi@indiana.edu

(c) Санкт-Петербургский государственный университет, 2018 
ставит вопрос об аутентичности содержащейся в них информации. Однако широкого обзора русских источников с такого рода анализом в историографии нет. Автор статьи изучил важнейшие из «посмертных» источников, не заходя, впрочем, далее XVII столетия. Это широкий круг памятников письменности от жития митрополита Филиппа до повестей конца XVII в. Внимательный анализ показал наличие большого компендиума исторических ошибок в повествованиях об Иване Грозном. В историографии этому до сих пор не придается должного значения, хотя, как отмечено в статье, ошибки продолжают оказывать значительное влияние на современную историческую мысль. Используя новейшие достижения современной исторической науки, в частности, в области изучения исторической памяти, автор статьи попытался разобраться в проблеме происхождения таких ошибок. При этом он сравнил московскую ситуацию с тем, что было в Западной Европе того же времени и пришел к выводу, что в московской традиции ошибки в трактовке жизни и деятельности Ивана Грозного отнюдь не связаны с тем, что Московия не пережила тогда в отличие от Западной Европы «печатную революцию». Изучение данной проблемы позволило автору сделать пять важных наблюдений: 1) особой печатной «революции» не было, это был скорее процесс, чем революция; 2) типографские ошибки сменили рукописные; 3) предубеждения и пристрастия доминировали даже в относительно добросовестных произведениях; 4) печатное дело не элиминировало старые легенды и мифы и, наконец, 5) хотя печатные произведения могли содержать легенды о более ранних персонажах, при освещении относительно близких по времени правителей они более аутентичны. Историческая память всегда избирательна, и ошибки по оплошности столь же часты, как и ошибки по умыслу.

Ключевые слова: Иван Грозный, Московия, историческая память, печатные книги, рукописные источники.

Because so many contemporary sources about the reign of Tsar' Ivan the Terrible have survived only in manuscripts that post-date his death, and because so many sources composed after his death contain so much original information about his reign, the question of Ivan's presentation in Muscovite historical memory, from 1584 until approximately the end of the seventeenth century, is very relevant to evaluations of Ivan's life and times. This article discusses the extent to which errors in later sources reflect ignorance of sixteenth-century Russian history, not his image. Although a few scholars have made isolated comments about the ignorance of individual authors or texts, no one has systematically posed this question as far as the the corpus of relevant sources as a whole is concerned. Doing so leads to the conclusion that ignorance of Ivan's reign in Muscovite historical memory was far greater than has been appreciated. That Muscovite historiography remained in manuscript raises the question of how much this ignorance can be attributed to Muscovy's failure to join the "Print Revolution".

Identifying authorial ignorance poses a number of methodological problems. Ivan's Muscovy was a manuscript culture, which produced only a few, exclusively religious, printed books, so preservation of the historical record depended upon copyists. Distinguishing an author's error deriving from ignorance from a copyist's error deriving from carelessness can be difficult. The applies particularly to dates, recorded via a system of letter equivalents and markers, not Arabic numerals. Furthermore, some errors of omission or commission were committed deliberately, for partisan purposes. Legends, ex post facto prophesies, and fantasies substitute for reliable historical information. Folklore, overwhelmingly recorded in the eighteenth century, can be excluded from this discussion, so by default I am concerned only with elite historical memory. Furthermore, it should be noted that aristocratic and gentry landowners retained family historical memory of 
properties lost during Ivan's tumultuous reign, which they sought to recover well into the seventeenth century. No sixteenth-century Muscovite family archives have survived so we cannot determine if such memories derived from saved written records or oral memory.

The methodological questions of whether late sources can contain previously unattested reliable information and whether credibility is relevant to a source as a whole, rather than its individual components, lie outside the scope of this essay. Although many seventeenth-century texts that discuss Ivan remain unpublished, more than enough have been published or summarized in scholarship to sustain an investigation. Because the dating of sources is not directly germane to my concerns, I have not summarized the relevant debates, although I have tried to present the sources in loose chronological order.

Historians disagree on how much influence Ivan IV's councilor Alexei Adashev exercised on the period of reforms in Ivan's reign, circa 1547 to circa 1560. In the year after Ivan's death, Stanislav Karnkovskii, Bishop of Gniezno, compared the role of Boris Godunov during the reign of Ivan's son, Tsar' Fedor Ivanovich, to the de facto rule previously exercised by Adashev. Muscovite poslannik Luk'ian Novosil'tsev categorically contested that comparison, claiming that Adashev, although intelligent, had a much lower status than the boyar, koniushii, and royal brother-in-law Godunov' ${ }^{1}$. Novosil'tsev knew who Adashev was, but was either ignorant of or chose to ignore that Adashev was an okolnichii, a rank below that of boyar in the Duma, held by Godunov.

According to the zhitie of Metropolitan Filipp from the $1590 \mathrm{~s}^{2}$, after Filipp became metropolitan, Ivan established the oprichnina. Filipp vigorously opposed that institution. He summoned the Osviashchennyi sobor of bishops and leading abbots to repudiate the oprichnina, but none of its members supported $\mathrm{him}^{3}$. Ivan had Filipp removed from office, incarcerated in a monastery, and then murdered.

In fact, Ivan created the oprichnina before Filipp became metropolitan. At first Filipp refused to accept the office unless Ivan abolished the oprichnina, but Ivan refused. Finally Filipp agreed to a compromise: in return for promising not to speak out against the oprichnina, a promise he eventually broke, Filipp retained the right as metropolitan to intercede for Muscovites Ivan accused of wrongdoing. Filipp's zhitie does not mention the charter that Filipp signed effectuating that compromise, perhaps from ignorance, but perhaps not, but the charter survives to this day and could have or should have been available to the hagiographer. However, it would not have served his purpose to demonstrate Filipp's flexibility in his opposition to the oprichnina. Ignorance does explain confusion in the various redactions of the zhitie over whether Ivan ordered the beheading of Filipp's brother or cousin, whose head Ivan sent to the imprisoned Filipp, which is an arguably fictional detail.

A second zhitie from 1590s, that of the iurodivii Vasilii Blazhennyi, also dates to the 1590s. According to this zhitie, when Ivan rode to the city of Novgorod to punish traitors, Vasilii took him to task. In one version he gave Ivan meat to eat, which Ivan rejected because it was a fast period in the Russian Orthodox Church; Vasilii then asked Ivan why

${ }^{1}$ Filiushkin A. I. Istoriia odnoi mistifikatsii. Ivan Groznyi i “Izbrannaia Rada”. Moscow, 1998. P. 242243.

${ }^{2}$ Lobakova I. A. Zhitie mitropolita Filippa. Issledovanie i tektsy. St. Petersburg, 2006. P. 149-280; Kolobkov V. A. Mitropolit Filipp i stanovlenie moskovskogo samoderzhaviia, Oprichnina Ivana Groznogo. St. Petersburg, 2004. P. 554-619.

${ }^{3}$ Lobakova I. A. Zhitie mitropolita Filippa. Issledovanie i tektsy. P. 152; Kolobkov V. A. Mitropolit Filipp i stanovlenie moskovskogo samoderzhaviia, Oprichnina Ivana Groznogo. P. 573. 
then he was shedding innocent blood, i.e. eating meat. When a contrite Ivan ordered the cessation of the repression, the cup of blood that Vasilii had given him to drink with the meat turned to sweet wine and the meat to watermelon. In another version Vasilii showed Ivan the souls of his innocent victims, which deflected Ivan's anger. Vasilii proved his supernatural powers by returning to Moscow faster than Ivan, who used the speedy Muscovite $y \mathrm{am}$. At another time Vasilii bowed to Ivan's first wife, Tsaritsa Anastasiia, explaining that she was the mother of a future saint, Tsarevich Dmitrii, who would die at the age of eight in his appanage at Uglich ${ }^{4}$.

Actually Vasilii died in 1557; he could not possibly have interfered with Ivan's repression of Novgorod in 1569-1570. No one restrained Ivan's sack of the city and executions. Vasilii's intercession in Novgorod was plagiarized from the iurodivii Nikola's intercession in Pskov, Ivan's next destination after Novgorod, where Nikola did apparently persuade Ivan to cease and desist, at least somewhat. Someone living in the 1590s should have known both that Vasilii was dead by 1569 and that the violence of Ivan's minions at Novgorod went unabated. Accounts of that repressive movement, which of course fail to mention Vasilii, survived in manuscripts and living memory beyond the 1590s, and some authors discussed in this essay knew better than to accept the zhitie's account. The anachronism of Vasilii's Novgorod actions, moreover, was superfluous, because saints can perform miracles posthumously. Vasilii could have induced Ivan to terminate his sack of the city and executions by responding to a prayer by a Novgorodian or by communicating with Ivan or someone else in a dream or vision. That Ivan would respond to a iurodivii is consistent with Ivan's attested behavior, as the case of Nikola in Pskov indicates.

Anastasiia did bear a son, Tsarevich Dmtrii, but he died before his first birthday in 1553. The Tsarevich Dmitrii of Uglich who died in 1591 and was later canonized was the son of Mariia Nagaia, Ivan's seventh wife. The zhitie misidentifies Saint Tsarevich Dmitrii's mother.

Kazanskaia istoriia is a lengthy narrative of Muscovy's relations with the Tatar khanate of Kazan' on the middle Volga River culminating in Ivan's 1552 conquest. Although some parts of the text may date to the 1560s, all surviving manuscripts date to the seventeenth century and contain anachronisms which could not have been written before the 1590s. Consequently, there is no way to extract passages contemporary to Ivan's reign from the extant texts, which is why I include it in this discussion.

Concerning Ivan, the contents of the narrative suggest misinterpretation, deliberate or not, rather than ignorance. The text praises Ivan inordinately for the success of his 1552 campaign, but notes that it would not have been slavno for Tsar' Ivan to have captured Kazan' on his earlier attempt, because there was no tsar' (here meaning "khan") on the throne at the time $e^{5}$. Ivan refuses to retreat because of a lack of supplies and the upcoming winter. If he had turned back, he would not have merited pokhvala. Ivan praises the defenders of Kazan' for fighting for the slava of their city ${ }^{6}$. However, Ivan never expressed any desire for personal fame or glory during his lifetime; officially at least, the conquest of Kazan' added to God's glory, not Ivan's. The sensitivity of Kazanskaia istoriia toward fame

${ }^{4}$ Kuznetsov I. I. Sviatye blazhennye Vasilii i Ioann, Khrista radi moskovskie chiudotvortsy // Zapiski Moskovskogo arkheologicheskago instituta. 1910. Vol. 8. P. 82, 91-92, 284-285.

5 Tsar' denoted both rulers of Muscovy after 1547 and descendants of Chinggis Khan, khans, ruling various Tatar states.

${ }^{6}$ Kazanskaia istoriia / ed. by G. N. Moiseeva. Moscow; Leningrad, 1954. P. 85, 137, 160. 
as a desirable virtue is anachronistic, projecting a seventeenth-century virtue on to the sixteenth century.

The 1617 Khronograf is now considered the work of Prince Semen Shakhovskoi. It declares that Ivan became tsar' after his conquest of Kazan' and Astrakhan'. At the urging of his second (unnamed) wife, Ivan supposedly divided the realm between himself, his appanage, called the oprichnina, and the rest, the zemshchina, which he gave to Tsar' Simeon of Kazan', a converted descendant of Chinggis Khan. Ivan resided in Staritsa, Simeon in Moscow. Some manuscripts insist that Mariia Nagaia was Ivan's third, not seventh, wife, and in a separate work Shakhovskoi counted Mariia Nagaia as Ivan's sixth wife. Later Ivan made war on King Stefan Batory of the Polish-Lithuanian Commonwealth (as part of the Livonian War). When Batory besieged the city of Pskov, out of fear Ivan negotiated a truce to end the war. After that his eldest son, Tsarevich Ivan, died in Moscow ${ }^{7}$.

Ivan was crowned tsar' in 1547, before his conquest of Kazan' in 1552 and Astrakhan' in 1556. If the 1617 Khronograf meant that Ivan "really" only became tsar', that is khan, after he had conquered a khanate, it does not clearly say so; instead, it just looks as if the author was ignorant of the chronology, readily available in various chronicle manuscripts at the time.

Simeon had been tsar' of Kasimov, Muscovy's serving Tatar khanate, not of Kazan'. Ivan did not place him in charge of the zemshchina between 1565 and 1572, but gave him the throne of Moscow in 1575, and took it back in 1576. Simeon had nothing to do with the oprichnina. Ivan's first residence in the oprichnina was not Staritsa but Aleksandrovskaia Sloboda; he temporarily moved to Staritsa only later. Tsarevich Ivan died in Aleksandrovskaia Sloboda, not Moscow.

For unknown reasons the main Moscow chronicle stops in 1567, and was never resumed during Ivan's reign. Its account of the creation of the oprichnina did not mention Simeon, of course, but does locate the oprichnina in Aleksandrovskaia sloboda. Some regional and private chronicles do mention where Tsarevich Ivan died.

The adult Ivan was afraid of no one, and a Russian Orthodox Christian tsar' cannot have feared a Catholic Polish king, because a tsar' outranked a king and Orthodox Christianity was superior to Catholicism, according to Ivan himself. The 1617 Khronografs interpretation of Ivan's diplomacy is both demeaning and inaccurate. Ivan made peace, for the moment, because Muscovy had exhausted its resources fighting the war. He fully intended to resume the war with Poland after he had dealt with another enemy, Sweden, although he died before he could do so.

Within a half century after the fact, the 1617 Khronograf had already conflated and distorted the two most idiosyncratic events of Ivan's reign, the creation of the oprichnina and the Simeon Bekbulatovich episode. This chronological error was perpetuated in other Muscovite sources and survives to this day in some modern historiography.

Several, but not all, short chronicles also connected Simeon to the oprichnina ${ }^{8}$. Various sources blamed a variety of evil advisors for the oprichnina, including Ivan's second

7 Pamiatniki literatury drevnei Rusi. Konets XVI - nachalo XVII vekov / eds D. S. Likhachev and L. A.Dmitriev. Moscow, 1987. P.358-361; Pamiatniki drevnei russkoi pis'mennosti, otnosiashchiesia k Smutnomu vremeni // Russkaia istoricheskaia biblioteka. Vol. 13. St. Petersburg, 1891. Cols. 561, 563, 847.

8 S. I. Khazanova fails to mention the 1617 Khronograf as doing so. Khazanova S. I. : 1) Oprichnina v Piskarevskom letopiste i letopisanie XVII veka // Arkhiv russkoi istorii. 2007. Vol. 8. P. 53-54; 2) Piskarevskii letopisets: Proiskhozhdenie, Istochniki, Avtorstvo. Moscow, 2014. P. 53-85. 
wife, the Circassian Mariia Cherkasskaia, and a bishop in the Trinity-Sergius Monastery 9 Sof'ia Khazanova identifies this bishop as Vassian Toporkov, whom boyar émigré Prince Andrei Kurbskii blames for Ivan's behavior based upon a conversation between Toporkov and Ivan that supposedly took place in 1553. Khazanova calls the title "bishop" an error as Toporkov was igumen of the monastery. Toporkov was actually the former bishop of Kolomna, but after his removal from that office in 1542 he resided in the Pesnosha Monastery of St. Nicholas, not the Trinity-Sergius Monastery, and he was never its abbot ${ }^{10}$. Daniil Al'shits observes that many short chronicles of the second half of the seventeenth century freely mixed historical facts with legends and pure fantasy ${ }^{11}$.

The clerk Ivan Timofeev wrote an account of the Smutnoe vremia focused on his native Novgorod ${ }^{12}$. He describes the oprichnina as dvoeverie, a term used to reference not, as later scholarship inferred, the mixture of pagan and Christian beliefs and practices, but simply non-standard, popular religious practices frowned upon by elite clerics ${ }^{13}$. When Ivan divided his realm in two, he selected Simeon Bekbulatovich, former tsar' of Kazan', to hold part of it, presumably the zemshchina ${ }^{14}$. Timofeev commits the same gross chronological error as the 1617 Khronograf.

Timofeev blames "barbarians" and immigrants for manipulating Ivan into turning against his people, and specifically into attacking Novgorod. He notes that "some say" that Boris Godunov and Bogdan Bel'skii poisoned Ivan IV and that "some say" that Ivan IV killed Tsarevich Ivan in a fit of temper ${ }^{15}$. These judgments are all in error: Ivan IV's decision to attack Novgorod was not influenced by foreigners, Ivan IV was not poisoned, and whether he murdered Tsarevich Ivan in a fit of temper is an open question ${ }^{16}$. Timofeev explicitly attributes these opinions to rumor, not manuscript written sources.

The Moskovskii letopisets of the early seventeenth century uniquely asserts that lay and ecclesiastical members of the elite objected to Ivan IV's elevation of Simeon Bekbulatovich because he had disrespected his elder son, Tsarevich Ivan, who should have been named as his successor. In retaliation, Ivan IV executed many of the complainers. A year later he retook the throne of the tsarstvie ${ }^{17}$. However, Simeon never held the title "Tsar' of All Rus", so Ivan could hardly have retaken the tsarstvie from him. No other source raises the issue of Tsarevich Ivan's status when Ivan abdicated to Simeon. Whether these executions were connected to Simeon's elevation remains under discussion ${ }^{18}$. The Moskovskii

\footnotetext{
${ }^{9}$ Khazanova S.I.: 1) Oprichnina v Piskarevskom letopistse... P.49-50; 2) Piskarevskii letopisets...P. 83 .

10 Prince A. M. Kurbsky's History of Ivan IV / ed. by J. L. I. Fennell. Cambridge, 1965. P. 80-81.

${ }^{11}$ Al'shits D.N. Drevnerusskaia povest' pro tsaria Ivana Vasil'evicha i kuptsa Kharitona Beloulina // Trudy otdela drevnerusskoi literatury. 1961. Vol. 17. P. 271.

12 Swoboda M. The Place of Novgorod in Ivan Timofeyev's Vremennik // Russian History. 1998. Vol.25, issue 4. P. 409-428; Keenan E. L. Who Was 'Ivan Timofeev'? // Harvard Ukrainian Studies. 20112014. Vol.32/33. P. 415-423.

${ }^{13}$ Rock S. Popular Religion in Russia. 'Double Belief' and the making of an academic myth. London, 2007.

14 Vremmenik Ivana Timofeeva / ed. by O. A. Derzhavina. Moscow; Leningrad, 1951. P. 11-13.

15 Ibid. P. 11-14, 15, 19.

16 Bushkovitch P. Possevino and the Death of Tsarevich Ivan Ivanovich // Cahiers du monde russe. 2014. Vol. 55, issue 1-2. P. 119-134.

17 Moskovskii letopisets. Polnoe sobranie russkikh letopisei. Vol. 34. Moscow, 1978. P. 226-227.

18 Khazanova S. I. Piskarevskii letopisets...P. 86-87; Ostrowski D. Simeon Bekbulatovich's Remarkable Career as Tatar Khan, Grand Prince of All Rus', and Monastic Elder // Russian History. 2012. Vol. 39, issue 3. P. 269-299, 339-345; Martin J. Simeon Bekbulatovich and Steppe Politics: Some Thoughts on Donald Os-
} 
letopisets repeats that "some people" say that Ivan was poisoned by blizhnye liudi ${ }^{19}$, which was not true.

The Piskarevskii letopisets contains considerable novel information on Ivan and his reign ${ }^{20}$. (Some of its information also appears in the Sokrashchennyi vremennik, discussed below.) Most scholars date it to the first quarter of the seventeenth century, some slightly later, and opinions on its authorship vary ${ }^{21}$. Some factual errors might be considered minor, such as calling Ivan Telepnev-Obolenskii, favorite of Ivan's widowed mother, Grand Princess Elena Glinskaia, an okol'nichii instead of a boyar and koniushii ${ }^{22}$. Other historical inaccuracies cannot be treated so lightly.

Piskarevskii letopisets makes Adashev its hero. Uniquely, it describes his accompanying his father on an embassy to Constantinople (Istanbul), where Alexei fell ill. Because of Adashev's illness, Ivan made his father a boyar and Alexei an okolnichii. Piskarevskii letpisets ascribes great and positive influence to him before the oprichnina. He and the priest Sylvester sat in the Blagoveshchenskii sobor, where Sylvester was a priest, and pravil the russkaia zemlia, bringing it peace, justice, and piety. He spent his non-working time in prayer and fasting. Ivan established the oprichnina on the evil advice of Vasilii Iur'ev and Alexei Basmanov. When the evils of the oprichnina increased, Ivan sent Adashev to Livonia and then sent someone there to kill him, but he died before the assassin arrived ${ }^{23}$.

It is highly improbable that Adashev could have carried out his governmental duties had he lived the ascetic saintly lifestyle attributed to him by the Piskarevsii letopisets. Ascribing such political dominance to Adashev and Sylvester was both politically tendentious and erroneous; Adashev served at Ivan's will and had no independent power base. Ivan certainly did not promote Alexei Adashev's father to boyar because of the otherwise unconfirmed illness of his son in Constantinople, nor would Ivan have needed to send an assassin to kill Adashev rather than just ordering his execution. Adashev's influence during Ivan's reign derives not from chronicles, which encompass the period of his entire life, but from the polemical correspondence between Ivan and Kurbskii and Kurbskii's "History of Ivan IV." Whether the seventeenth-century manuscripts of these texts predate the composition of the Piskarevskii letopisets is problematic given its uncertain dating.

The Piskarevskii letopisets uniquely describes Ivan in Kolomna in 1546 as engaging in some very confusing activities, plowing, planting, walking on stilts, and wearing a shroud,

trowski's Interpretation of the Tsar's Remarkable Career // Russian History. 2012. Vol.39, issue 3. P.331-338; Filjushkin A. The Mystery of a Political Masquerade (Concerning the Article of Donald Ostrowski) // Russian History. 2012. Vol.39, issue 3. P.301-305; Halperin C. J. Simeon Bekbulatovich and the Mongol Influence on Ivan IV’s Muscovy // Russian History. 2012. Vol.39, issue 3. P. 306-330.

19 Moskovskii letopisets... P. 229.

20 Piskarevskii letopisets / ed. by O. A. Iakovleva. Materialy po istorii SSSR. Vol. II. Dokumenty po istorii XV-XVII vv. Moscow, 1955. P.5-210.

21 Tikhomirov M.N. Piskarevskii letopisets kak istoricheskii istochnik o sobytiiakh XVI - nachala XVII v. // Russkoe letopisanie. Moscow, 1979. P. 232-247; Grekov I. B. Ob ideino-politicheskikh tendentsiiakh nekotorykh literaturnykh pamiatnikov nachala XVII v. (ob avtore Piskarevskogo letopistsa) // Kul'turnye sviazi narodov Vostochnoi Evropy v XVI v. Problemy vzaimootnoshenii Pol'shi, Rossii, Ukrainy, Belorusii i Litvy v epokhu Vozrozhdeniia. Moscow, 1976. P.329-358; Morozov S. A. K izucheniiu istochnikov Postnikovskogo i Piskarevskogo letopistsev. Letopisi i khroniki. Moscow, 1985. P. 59-74; Solodkin Ia. G. Po povodu atributsii Piskarevskogo letopistsa // Trudy otdela drevnerusskoi literatury. 1990. Vol. 44. P. 387-396; Khazanova S. I. 1) Oprichnina v Piskarevskom letopistse... P. 51-59; 2) Piskarevskii letopisets...

${ }^{22}$ Piskarevskii letopisets ... P. 48, N. 17.

${ }^{23}$ Ibid. P. 56. 
in what appears to have been a pagan fertility rite or magical ceremony ${ }^{24}$. Some scholars link whatever Ivan was doing here to accusations or descriptions of his engaging in profane "games" 25 but those passages probably refer to Ivan's well-known predilection for skomorokhi and their dancing bears, frowned upon by the Russian Orthodox Church ${ }^{26}$, not to the more exotic activities ascribed to him in Kolomna. Whatever Ivan was doing in 1546, for a young Orthodox Christian grand prince his behavior was sacrilegious at worst, unseemly at best.

No ambiguity attaches to several unique, critical passages of the Piskarevskii letopisets related to the oprichnina. Metropolitan Makarii, who died in 1563, was asked by Ivan for a book to read. Makarii had a vision, a premonition of future bloodshed, which induced him to send Ivan a book of the funeral service. Ivan angrily objected to such a gift, but Makarii replied that reading this book would save him from sin. The Piskarevskii letopisets explicitly dates this conversation to before the creation of the oprichnina with its spilling of innocent blood ${ }^{27}$. Likewise it records the prophesy of the tsaritsa (khansha) of Kazan' upon hearing of the Ivan's birth in 1530, that a boy had been born with two sets of teeth. With one he would devour Kazan', and with the other he would devour Muscovy, arguably a clear reference to the oprichnina ${ }^{28}$. The Makarii case requires forgetting that no contemporary source ever ascribed prophetic powers to him, nor recorded his engaging in such extreme criticism of Ivan. While there were tensions between the two over various issues of church-state relations, this passage in the Piskarevskii letopisets almost turns Makarii into Metropolitan Filipp ${ }^{29}$. Although Piskarevskii letopisets blames evil advisors for the creation of the oprichnina, it accords Ivan full responsibility for its injustices, atrocities, and destruction. Accurately it describes the oprichniki as wearing black clothes and riding horses with brooms, although it omits the dogs' heads ${ }^{30}$.

The Piskarevskii letopisets writes that Ivan forced his cousin, the appanage Prince Vladimir Andreevich Staritskii, together with his wife and one daughter, to take poison, but permitted one son (Vasilii Vladimirovich) and one daughter of Staritskii to live. The daughter married Duke Magnus, Ivan's puppet king of Livonia ${ }^{31}$. However, Ivan let two daughters live. The older was affianced to Magnus first, but died before the wedding, so the younger daughter took her place. The Piskarevskii letopisets also probably invented shameful goings-on at Vasilii's wedding, which Khazanova describes as deliberately tendentious, a conscious falsification to blacken Ivan's reputation ${ }^{32}$, and that Ivan later ordered his execution. That Ivan poisoned his second wife, Mariia Cherkasskaia, is not cred-

${ }^{24}$ Ibid. P.73-74.

${ }^{25}$ Khazanova S. I. Piskarevskii letopisets...P. 89-90.

${ }^{26}$ Zguta R. Russian Minstrels. A History of the Skomorokhi. Philadelphia, 1978. P.XIV, 42, 54-55, 63, 81-82, 95-99, 112.

${ }^{27}$ Piskarevskii letopisets ... P. 75.

${ }^{28}$ Ibid. P. 86. - S. I. Khazanova likens the remarks of the khan's wife to those in a short chronicle that her son would be an autocrat (Khazanova S. I. Piskarevskii letopisets...P. 92), but rulers before Ivan were described as "autocrats," and the term had multiple meanings, not just the pejorative one of despot assumed by Khazanova (Halperin C. J. Ivan IV as Autocrat (samoderzhets) // Cahiers du monde russe. 2014. Vol.55, issue 3/4. P. 197-213).

${ }^{29}$ Halperin C.J.Metropolitan Makarii and Muscovite Court Politics during the Reign of Ivan IV // Russian Review. 2014. Vol.763, issue 3. P. 447-464.

${ }^{30}$ Piskarevskii letopisets ... P.76; Halperin C. J. Simeon Bekbulatovich and the Mongol Influence ...

${ }^{31}$ Piskarevskii letopisets... P.76, 78; Khazanova S. I. Piskarevskii letopisets...P. 82.

32 Khazanova S.I. Piskarevskii letopisets...P. 91. 
ible; the chronicle also errs in dating the 1569 death of Cherkasskaia and the 1574 death of Vasilii Vladimirovich to the same year.

The Piskarevskii letopisets seems to date the 1571 executions on Krasnaia ploshchad' before, rather than after, the 1569-1570 sack of Novgorod. It also errs in ascribing the 1569 death of Ivan's second wife, Mariia Cherkasskaia, to the same year in which he married Marfa Sobakina, which took place two years later ${ }^{33}$.

After the Crimean burning of Moscow in 1571, Ivan, according to the Piskarevskii letopisets, appeared before the Crimean envoy who demanded $v y k h o d$, wearing a robe of coarse heavy cloth and pig fur, pleading poverty after the Crimean raid, during which the city of Moscow was virtually burned to the ground, as an excuse not to pay ${ }^{34}$. While not inconsistent with Ivan's theatricality, this episode too is unlikely. Ivan's sense of his own dignity would have precluded his dressing like a poor slob in public.

It is not credible that Ivan sent the heads of beheaded boyar and clerical victims to the courts of the metropolitan, boyars, and other leading court personages (a motif in the zhitie of Metropolitan Filipp). The list of victims in the Piskarevskii letopisets does not coincide with that in the Moskovskii letopisets, which did not specify that they were beheaded or how Ivan disposed of their heads. Nor did Ivan have Simeon Bekbulatovich crowned in the Uspenskii sobor or assign him the tsarstvo, because he never held the title of tsar' of Moscow $^{35}$.

That Ivan got his elite drunk at a banquet entertained by improper amusements and had spies write down what they said is implausible, because no Muscovite boyar would have been self-destructive enough to get drunk in Ivan's presence. Supposedly Ivan was amazed that his wise councillors spoke like simpletons when drunk, something no one who has spent time in the company of the inebriated would find the least bit surprising. Ivan enjoyed being entertained by skomorokhi, so that part of the scandal story rings true. That Ivan sent spies to discover the popular mood in the market dubiously assumes that Ivan valued public opinion; he always insisted that he answered only to God, not to the people, and if he were suspicious of plots against him, he would not have looked for such treason among commoners, but among the elite. Supposedly Ivan was amazed at the amount of popular volnenie. Historians interpret this passage as evidence of opposition to the oprichnina, although we cannot corroborate that this incident took place during the oprichnina. It is debatable whether anyone in the market place would speak out loud against Ivan's actions ${ }^{36}$.

The Piskarevskii letopisets lists only six, not seven, wives of Ivan, omitting the sixth, Vasilisa Melent'eva, but confusion over how many times Ivan married has lasted until very recent scholarship ${ }^{37}$.

Mikhail Tikhomirov concedes that the Piskarevskii letopisets contains some confused or inaccurate information, and sometimes contradicts other sources. Khazanova suggests the possibility that the chronicler was just poorly informed of the fate of Vasilii Vladimirovich ${ }^{38}$. She attributes the descriptions of the 1546 Kolomna episode, Vasilii Staritskii's

33 Piskarevskii letopisets... P. 78-79.

34 Ibid. P.79.

35 Ibid. 81-82.

36 Ibid. P. 85.

37 Ibid. P. 86; Martin R.E. A Bride for the Tsar: Bride-Shows and Marriage Politics in Early Modern Russia. DeKalb, 2012. P. 112-166.

${ }^{38}$ Khazanova S. I. Oprichnina v Piskarevskom letopiste i letopisanie XVII veka... P. 58. 
wedding, prophesies of the oprichnina, and Ivan's spying at his banquet and the market, to oral sources ${ }^{39}$, whose credibility she judges rather optimistically. Oral sources are comparable in credibility to unconfirmed contemporary rumor. The chronological errors of the Piskarevskii letopisets could easily derive from ignorance, especially given the incomplete narrative record of events after 1567 . While some of its fictitious stories resonate with similar reports in other sources, unique critical accounts of Ivan's actions might have been the creations of its compiler.

The early seventeenth-century Povest'o dvukh posolstvakh contains what is supposedly a diplomatic report of a 1570 Muscovite embassy to Constantinople, which describes how the Muscovite ambassador took such umbrage when the sultan insulted Ivan that he drew a knife and lurched at him. It also contains two apocryphal letters, a letter of credence by Ivan for the ambassador to the sultan, and a letter of the sultan to Ivan. In the 1640s a new, textually unrelated, set of the two epistles appeared. According to Daniel Waugh, none of these works is genuine. For literary or polemic purposes they all exalted Ivan's status and insulted the Ottoman ruler ${ }^{40}$.

During his reign Ivan sought at all costs not to displease the Ottoman Empire, the strongest power in Europe. Obviously no Muscovite ambassador would have tried to stab the sultan for insulting Ivan, but then again, no Ottoman sultan would have insulted Ivan, because the Ottomans favored trade with Muscovy ${ }^{41}$, and Ivan would never have insulted the sultan in official diplomatic correspondence ${ }^{42}$.

I am not certain that the epistles tilt toward a favorable image of Ivan. It is conceivable that the lengthy title Ivan claims comes across as just as pompous as the sultan's. In the earlier version of Ivan's epistle, Ivan chelom b'iu his "eldest brother" the sultan in friendship and love. The phrase for petition no longer literally meant kowtow, it had become a polite form of address, but only of an inferior to a superior, in this case, a younger brother to an elder brother ${ }^{43}$. To interpret this phrasing as praise of Ivan necessitates treating it as satire. On the other hand, the sultan praises Ivan for punishing his rebellious subjects (the oprichnina?), which might just as easily constitute sarcasm. In the second redaction of the epistle Ivan makes fun of the sultan's demand that Ivan pay tribute, which could never have happened because the sultan never demanded tribute. Ivan's condescending assertions of his superiority as an Orthodox Christian ruler to an "unbeliever" expresses genuine Christian bias ${ }^{44}$, but totally contradicts historical reality. Ivan constantly strove to

${ }^{39}$ Khazanova S. I. Piskarevskii letopisets...P. 93.

40 Waugh D. C. The Great Turkes Defiance. On the History of the Apocryphal Correspondence of the Ottoman Sultan in its Muscovite and Russian Variants. Columbus, 1978. P. 173-195.

${ }^{41}$ On the actual diplomatic report of I. P. Novosil'tsev to Istanbul in 1570 see: Halperin C. J. Russia Between East and West: Diplomatic Reports During the Reign of Ivan IV // Saluting Aaron Gurevich. Essays in History, Literature and Other Subjects / eds Yelena Mazour-Matusevich and Alexandra S. Korros. Leiden, 2010. P. 81-103.

${ }^{42}$ The sultan in the second set of epistles addresses Ivan as "White Ivan," an echo of Nogai Tatar usage of the term "White Tsar" for Ivan, meaning Western Tsar in the steppe color scheme. This was praise, not insult (Halperin C. J. Ivan IV and Chinggis Khan // Jahrbücher für Geschichte Osteuropas. 2003. Bd. 51, issue 4. P. 487-496).

43 Waugh D. C. The Great Turkes Defiance... P. 220-221; Poe M. What Did Russians Mean When They Called Themselves 'Slaves of the Tsar'? // Slavic Review.1998. Vol. 57, issue 3. P. 588, 599, 608.

${ }^{44} \mathrm{Kagan}$ M. D. Legendarnaia perepiska Ivana IV s turetskim sultanom kak literaturnyi pamiatnik pervoi chetverti XVII v. // Trudy otdela drevnerusskoi literatury. 1957. Vol.13. P.269-272. 
convince the sultan that Muscovy did not discriminate against Muslims, lest the Defender of the Faith take umbrage.

Obviously for literary ends the Povest' o dvukh posolstvakh present a fictional image of Muscovite-Ottoman diplomatic relations and correspondence during Ivan's reign. Such a cavalier attitude toward the historical Ivan entails the kind of psychic distance reflective of a lack of historical reverence for Ivan's memory ${ }^{45}$.

The Sokrashchennyi vremennik from the middle of the seventeenth century shares a common source with the Piskarevskii letopisets, which Khazanova optimistically dates to the late sixteenth century, after Ivan's death ${ }^{46}$. It contains substantively but not textually identical information on Iur'ev and Basmanov as manipulating Ivan to establish the oprichnina, on Ivan's poisoning of Mariia Cherkasskaia, and on Ivan's six wives, omitting Melent'eva. In addition, in that list Anna Koltovskaia erroneously follows Anna Vasil'chikova, whom she should precede ${ }^{47}$. However, while mentioning Ivan's black clothes in the oprichniki, it omitted the brooms on their horses ${ }^{48}$. In the Sokrashshchennyi vremennik Ivan sends the heads of his victims only to Prince Ivan Mstislavskii, not to multiple court and ecclesiastical figures as in the Piskarevskii letopisets, which is probably just as wrong ${ }^{49}$. After repeating the entry in the Piskarevskii letopisets on Simeon Bekbulatovich's coronation in the Uspenskii sobor, it adds that his wedding was held there as if it were the wedding of a tsar'50, because the Sokrashchennyi vremennik does erroneously accord Simeon the rank of tsar' referring to the ceremony "asit" if were for a tsar is a gratuitous slur on Simeon's wedding. Considering how many historians conceive of Simeon's tenure on the throne of Moscow as a "second oprichnina," it is intriguing that the Sokrashshchennyi vremennik describes Ivan as living outside the Kremlin, in the Petrovka neighborhood of Moscow, in both instances. In the description of Ivan's scruffy attire to greet the Crimean ambassador, the chronicler or a later copyist distorted the word for tribute, from vykhod to vyvod ${ }^{51}$. The narrative in the Sokrashshchennyi vremennik of the death of Tsarevich Ivan directly blames Ivan, who, it claims, struck his son with his iron-tipped staff in the leg, not on the head as in Possevino's version ${ }^{52}$. As we shall see, in the 1676 the Latukhinskaia stepennena kniga Ivan uses his iron-tipped staff to impale the foot of Kurbskii's servant Vasilii Shibanov while Kurbskii's First Epistle to Ivan is read aloud. Khazanova interprets the confusion of the Sokrashshchennyi vremennik over Ivan's stabbing his son in the foot or the head to a mix-up with the already-known Shibanov story ${ }^{53}$. It is dubious that any chronicler would confuse the son of a tsar' with the servant of a boyar-traitor, or think a stab wound to the foot fatal, regardless of whether the mistake was committed by the compiler or the copyist.

Nikolai Karamzin quoted a still unpublished chronicle that dates Ivan's sexual promiscuity to 1560 , in the aftermath of the death of his first wife, Anastasiia, to explain Ivan's decision at the time to move his two sons and two wards out of his personal living

45 Halperin C. J. The Defeat and Death of Batu // Russian history. 1983. Issue 10. P. 50-65.

46 Sokrashchennyi vremennik / ed. by O. A. Iakovleva. Materialy po istorii SSSR. Vol. II. Dokumenty po istorii XV-XVII vv. Moscow 1955. P. 145-165; Khazanova S. I. Piskarevskii letopisets... P. 76, 77, 79, 81.

47 Sokrashchennyi vremennik... P. 145, 147, 148.

48 ibid. P. 146.

49 Ibid. P. 148.

50 Ibid.

51 Ibid. P. 147.

52 Ibid. P. 148.

53 Khazanova S. I. Piskarevskii letopisets...P. 84. 
quarters and into separate "courts," so that they would not get in the way of his orgies. The manuscript he cited was a narrative of Orthodox metropolitans up to Metropolitan (Ivan) Mohyla (of Kiev), who assumed that office in 1632, so the chronicle is of mid seventeenth-century origin ${ }^{54}$. No reliable contemporary evidence validates this late accusation against Ivan's personal behavior immediately after Anastasiia's death. This slander reflects Ivan's blackest reputation, found in Kurbskii's "History" and foreign accounts, but it is unique to this text.

Stepennaia kniga is an authentic source from Ivan's reign, but its seventeenth-century Khrushchev redaction contains a speech that Ivan supposedly delivered to a 1549 zemskii sobor, admittedly an anachronistic term invented by later historians, held in Krasnaia ploshchad' at Lobnoe mesto. Because in it Ivan promises to reconcile all segments of Muscovite society, this supposed gathering has been labeled the Sobor primireniia in historiography. Ivan blames the abuses by the boyars during his youth on his youth, promises to end such injustice, but offers an olive branch to the offenders: if they cease and desist their misdeeds, all their previous crimes will be forgotten and forgiven. Ivan appoints Adashev, whom Ivan had raised from poverty, to establish and lead a Chelobitnyi prikaz, to hear complaints, and admonishes him to treat all such complaints equally, no matter the rank of the petitioner or alleged criminal perpetrator ${ }^{55}$.

The speech is a forgery ${ }^{56}$. During the sixteenth century no zemskii sobor ever met on Krasnaia ploshchad'. Adashev was hardly raised from poverty; he came from a respectable gentry family from Kostroma district. No source verifies the creation of a Chelobitnyi prikaz in 1549 or its existence in the immediately following years. Indeed, no Muscovite or foreign source confirms that any zemskii sobor took place in 1549, so Ivan could not have spoken to a fictitious gathering. V. Avtokratov interprets this forgery as an allegorical comment on issues of late seventeenth-century history, but regardless of its function, the speech takes great liberties with sixteenth-century history, from ignorance or propagandistic purposes.

In 1676 igumen Tikhon of the Makar'evskii Zheltovodskii Monastery compiled another redaction of the Stepennaia kniga, called the Latukhinskaia Stepennaia kniga. It asserts that Tsaritsa Anastasiia alone had the ability to calm Ivan down to the point that he could show mercy to the guilty or his enemies. Her death unleashed a storm that perverted his mind, changing him from wise to fierce, as Karamzin's chronicle portrayed that time. He began to destroy Muscovy's elite. Evil plots detached Ivan from his son Tsarevich Ivan. "Some say" that Ivan's anger induced Tsarevich Ivan's fatal illness ${ }^{57}$.

After Ivan married Mariia Nagaia, her family turned Ivan against Boris Godunov, but upon visiting Godunov's residence, his anger ameliorated. Hearing that the merchant An-

54 N.M.Karamzin cited Synodal Manuscript 364, folio 839 verso, now Synodal Manuscript 483 (Karamzin N. M. Istoriia gosudarstva Rossiiskago. Vol.9. St. Petersburg, 1892. P. 12, N 28). Edward L. Keenan kindly identified it for me (personal communication, 18 March 2009), citing: Tikhomirov M. N. Kratkie zametki o letopisnykh proizvedeniiakh v rukopisnykh sobraniiakh Moskvy. Moscow, 1962. P. 179.

55 Sobranie gosudarstvennykh gramot i dogovorov, khraniashchikhsia v Gosudarstvennoi Kollegii inostrannykh del Vol.2. Moscow, 1819; Russkii khronograf 1512 g. // Polnoe sobranie russkikh letopisei. Vol. 22, Pt. 1. St. Petersburg, 1911. P. 528-529.

56 Avtokratov V.N. "Rech' Ivana Groznogo" kak politicheskii pamflet kontsa XVII veka // Trudy otdela drevnerusskoi literatury. 1955. Vol. 11. P.255-279.

57 Latukhinskaia Stepennaia kniga. 1676 g. / eds N. N. Pokrovskii and A. V.Sirenov. Moscow, 2012. P. 537-539; Khazanova S. I. Oprichnina v Piskarevskom letopiste i letopisanie XVII veka... P. 50-51. 
ika Stroganov had facilitated Godunov's recovery from his wounds, Ivan raised Stroganov to the rank of gost ${ }^{58}$.

The Latukhinskaia Stepennaia kniga narrates the emotional scene when Prince Andrei Kurbskii said goodbye to his wife and nine-year-old son before he skipped the country on horses prepared by his loyal rab Vasilii Shibanov. She lovingly kisses him, and urges him to flee alone, because with his family holding him back he would fail to cross the border safely. Once in Lithuania Kurbskii writes an epistle to Ivan. Shibanov delivers it to Ivan in Moscow, identifying himself as Kurbskii's loyal servant. Ivan pinned Shibanov's foot to the ground with his iron-pointed staff, forcing him to endure excruciating pain as the letter was read aloud, but Shibanov remained faithful to his master ${ }^{59}$.

Inspired by the Devil, Ivan gave in to anger and fury, oppressing the boyars because of evil advice. He held a council, which included the Osviashchennyi sobor, to discuss his plan to divide the realm. Metropolitan Filipp, supported by one bishop, opposed the plan, but the other bishops were afraid of Ivan's anger ${ }^{60}$.

Finally, an unnamed archpriest of the Blagoveshchenskii sobor, Ivan's dukhovnyi otets, argued with him, so Ivan ordered him executed. Ivan personally stabbed him with his iron-tipped walking staff, after which the priest was buried alive in the ice ${ }^{61}$.

Anatasiia's calming influence on Ivan remains highly popular in some modern historiography, but cannot be confirmed. In blaming Anastasiia's death for Ivan's moral degeneration, Tikhon disregards chronology. Anastasiia died in 1560, but Ivan did not begin the process of establishing the oprichnina until 1564. Furthermore, Ivan's change of character is over-determined: in addition to the death of Anastasiia, Tikhon mentions the Devil and evil advisors as causes as well. Any connection between Anastasiia's death in 1560 and the death of Tsarevich Ivan in 1581 is farfetched.

Like Timofeev, and equally vaguely, Tikhon relates the death of Tsarevich Ivan to Ivan IV's anger, but without the declaration of other sources that Ivan directly and physically killed Tsarevich Ivan. Some short chronicles and chronographs write that Ivan IV killed Tsarevich Ivan, some mention the iron-tipped staff, but others do not, and some just relate that he died ${ }^{62}$.

The scene in the Latukhinskaia stepennena kniga of Ivan's sickbed encounter with Boris Godunov and subsequent promotion of Stroganov are fictional. There is no evidence of tension between Ivan and Godunov even after Tsarevich Fedor became heir-apparent. Kurbskii's tearful farewell to his family cannot possibly be based upon reliable evidence; we know only that Kurbskii did indeed leave his wife and family in Muscovy when he fled. The Shibanov episode, aside from making Shibanov look good and Ivan look like a sadist, is entirely invented. Shibanov was caught in Muscovy and executed, but he was caught by accident, he had no intention of suicidally hand-delivering his master's epistle to Ivan. Ivan did not hold a combined meeting of the Duma and Osviashchennyi sobor to discuss the creation of the oprichnina. The detailed narrative of his actions at the time, in the Aleksandro-Nevskiai letopis', a part of the Litsevoi letopisnyi svod, describes Ivan as leaving Moscow without telling anyone of his destination or purpose. Ivan did not mention the

\footnotetext{
${ }^{58}$ Latukhinskaia Stepennaia kniga... P. 538.

59 Ibid. 542-543.

${ }^{60}$ Ibid. P. 544-547.

${ }^{61}$ Ibid. P. 547.

${ }^{62}$ Khazanova S. I. Oprichnina v Piskarevskom letopiste i letopisanie XVII veka... P. 56-57.
} 
oprichnina until a delegation from Moscow arrived in Aleksandrovskaia Sloboda to ask him not to abdicate. Tikhon ignores that narrative entirely ${ }^{63}$. He also seemingly departs from one of his sources, the zhitie of Filipp, in writing that one bishop supported Filipp's opposition to the oprichnina. The archpriest of the Blagoveshchenskii sobor was Ivan's confessor, but Ivan never executed anyone occupying that position.

In short, virtually all original passages about Ivan's reign in the Latukhinskaia stepennena kniga seem to contradict contemporary sources in details or context. Tikhon's novel embellishments of his sources derive from his imagination, legend, or fantasy, because of his ignorance, or despite the accurate knowledge he could have acquired from extant manuscripts.

The Skifskaia istoriia of Andrei Lyzlov was printed in 1692. From the Kazanskaia istoriia Lyzlov repeated the possibility that Ivan had failed to take Kazan' before 1552 because there would have been no glory in defeating the Kazan' Khanate when it had no khan ${ }^{64}$. According to Lyzlov, in 1572 Ivan was so annoyed at the demands of the Crimean envoys that he ordered their lips, noses, and ears cut off and then sent them to the Crimean Khan. After that, the throne was surrounded by ryndy with axes, not swords ${ }^{65}$.

Of course Ivan never ordered the mutilation of any Crimean envoys. In addition, axe-carrying ryndy surrounded the royal throne in receptions going back to the 1550s. Lyzlov's atrocity story about Ivan's treatment of the Crimean envoys does not criticize Ivan, which says more about Lyzlov than Ivan, but either way it is obviously fantasy. When Ivan was displeased with envoys, Crimean or otherwise, he kept them imprisoned, refused to see them, cut their rations, or insulted the ruler who had sent them by not standing or taking off his hat when the ruler's name was mentioned, which is exactly what European rulers did to Muscovite envoys who displeased them. In exceptional circumstances assault and robbery might also be employed to coerce envoys, but mutilation was not an option ${ }^{66}$. The historical errors in Skifskasia istoriia may reflect seventeenth-century policy disputes over the Crimea, but also ignorance of sixteenth-century Muscovite history. Elena Chistiakova comments on the many errors in dates and facts in the portions of the text dealing with the conquest of Kazan'67.

From a manuscript of a Novgorod chronicle copied in 1822 comes a story about Ivan's reign which strikes me as Muscovite, not Imperial, in origin, so I include it here. In 1571 Petr Volynets reveals to Ivan plots against him in Novgorod. Ivan does not believe the denials by the accused and orders the execution of everyone, man, woman, and child, with the sole exception of the metropolitan. In one day 2,770 Novgorodians met their deaths. Ivan replaced terminated gentry clans with princely and non-princely boyars from the Muscovite heartland, who were resettled in Novgorod district. From that time on, Ivan did not trust his subjects, but Volynets got rich. Implicitly, he profited from his false denunciations of innocent Novgorodians ${ }^{68}$.

${ }^{63}$ Aleksandro-Nevskaia letopis' // Polnoe sobranie russkikh letopisei. T. 29. Moscow, 1965. P. 341-345.

${ }^{64}$ Lyzlov Andrei. Skifskaia istoriia / eds E. V. Chistiakova and A. P. Bogdanov. Moscow, 1990. P. 64.

65 Ibid. P. 147.

${ }^{66}$ For a different interpretation of Skifskaia istoriia see: Boeck B. J. The Don Interpolation: An Imagined Turning Point in Russian Relations with the Tatar World // Dubitando. Studies in History and Culture in Honor of Donald Ostrowski / eds Brian Boeck, Russell E. Martin and Daniel B. Rowland. Bloomington, 2012. P. 129-138.

${ }^{67}$ Lyzlov Andrei. Skifskaia istoriia... P. 368.

${ }^{68}$ Novgorodskie letopisi. Vol. 2 / ed. by A. I. Tsepkov. Riazan, 2002. P. 468-469. 
The head of the Novgorod eparchy was promoted from archbishop to metropolitan in 1589, when the metropolitan of Moscow was raised to patriarchal status; this anachronism marks the tale as post-Ivan. The number of Novgorodian dead in one day is in the same range as that in the memorial lists of his victims that Ivan sent to monasteries with money for prayers for the dead in 1581, approximately 3,200 from Novgorod of approximately 3,300 overall, but any connection to the 1822 count would be speculative ${ }^{69}$. The Novgorod chronicler has confused Ivan IV with his grandfather Grand Prince Ivan III (also Ivan Vasilevich), Velikii, although both were called the Groznyi in the seventeenth and eighteenth centuries $^{70}$. Ivan III moved Muscovite gentry onto Novgorod lands confiscated after he annexed the city; overwhelmingly the Muscovite "immigrants" were gentry, but boyars received some lands too. The chronological ignorance of Ivan IV's reign demonstrated by such an error is considerable. Certainly evidence that Ivan IV distrusted Russians, especially but not exclusively boyars, predates the sack of Novgorod; the chronicler overlooked decades of Ivan IV's reign.

From the late seventeenth or early eighteenth century comes the Povest'o Kharitone Belouline $^{71}$. According to its earliest redaction, in 1572 Tsar' Ivan IV learned that the death of Tsarevich Ivan the previous year was caused by evil traitors, so in Moscow he ordered the preparation in Pozhar of 300 plakha, 300 axes, and 300 palachi. He summoned people of every rank to attend and to be executed. Ivan rode onto Krasnaia ploshchad' in black dress on a black horse. Each executioner chose a victim from a list of imenitye people. They started with the second tier of the merchant elite, members of the gostinnaia sotnia. After seven executions, the eighth victim, Khariton Beloulin, was too big to fit on the block. He asked the tsar' why he was executing innocent people. Pisari assisted the executioners in holding Beloulin down to be beheaded, but afterward his body kept moving. Ivan was amazed and in fear left the square for his palace. No one moved from the square without the tsar's permission. Three hours later Ivan sent permission to release those seized. The corpse kept moving all day and into the night. The next morning the tsar' ordered the bodies to be buried ${ }^{72}$.

The motif of the body of a beheaded man continuing to move as if alive is wellknown in folklore and hagiography ${ }^{73}$. The 300 blocks, axes, and executioners is a folklore motif. Clearly the tale is a-historical and illogical. Ivan IV chooses to execute not those responsible for Tsarevich Ivan's death but random innocent people. The historical Moscow executions took place in 1571 on Krasnaia ploshchad', and the Pozhar is a nearby merchant district, but Tsarevich Ivan's death occurred in 1581. Ivan could only have dressed in black and ridden a black horse from 1565 until 1572, during the oprichnina. As in the 1617 Khronograf, Ivan experiences fear - as one might expect in the presence of a miracle, but the description of Ivan's reaction is not flattering. He was afraid because he was caught doing evil.

${ }^{69}$ Skrynnikov R. G. Tsarstvo terrora. St. Petersburg, 1992. P. 529-544.

70 Halperin C. J. The Metamorphosis of Ivan IV into Ivan the Terrible // Miscellanea Slavica. Sbornik statei k 70-letiiu Borisa Andreevicha Uspenskogo / ed. by F. B. Uspenskii. Moscow, 2008. P. 379-397.

${ }^{71}$ Al'shits D. N. Drevnerusskaia povest' pro tsaria Ivana Vasil'evicha i kuptsa Kharitona Beloulina... P. 256.

72 The secondary redaction drops a number of these elements from the Tale (Al'shits D. N. Drevnerusskaia povest' pro tsaria Ivana Vasil'evicha i kuptsa Kharitona Beloulina... P. 268-270).

${ }_{73}$ On St. Mercurius of Smolensk, beheaded by Batu Khan, see: Halperin C. J. The Defeat and Death of Batu. P. 50-65. 
To search for historical verisimilitude in such a fantasy seems futile. Its chronological anomalies qualify as reflections of historical ignorance. Al'shits suggests that such errors can be attributed to the carelessness of later copyists ${ }^{74}$, but ignorance seems a better explanation.

The ignorance of post-Ivan Muscovite authors of the facts of Ivan's life and reign resulted from multiple causes. Absence of Muscovite sources, inaccessible sources, and copyists' errors, especially in dates, all played a role. Deliberate falsification because of ideological and partisan bias could distort accurate history even when it was known. It would be naive to believe that an author could only report baseless rumor and create fantasy in the absence of credible accurate information, because authorial bias could be decisive in determining what "facts" were considered credible and inevitably produce a tendentious account. Not all authors identified rumors as rumors. Clearly anachronistic fantasies, such as prophesies, must have been conceived post facto, but we know only when surviving written sources repeated them; if there was earlier oral transmission, by definition it left no written record. Distinguishing among rumor, tall tale, legend, and myth is not necessary; the problem for the historian studying Ivan's reign is to discriminate between reliable and unreliable information. Historians have different conceptions of the degree of "creativity" of seventeenth-century authors ${ }^{75}$, but erroneous "facts" are erroneous regardless of their source.

Because sixteenth- and seventeenth-century Muscovy was a manuscript culture, in which few books, almost entirely religious, were printed, it is reasonable to ask to what extent that manuscript culture contributed to the ignorance I have documented by making it harder for sources to survive or be disseminated. This raises a question posed by Walter Ong some time ago, namely, what was the impact of print upon historiography? ${ }^{76}$ Ong was thinking in terms of historical consciousness, which lies outside the scope of this article. Of course, print permitted much more rapid accumulation of a greater amount of material by a historian in a shorter time. What interests me in light of Muscovite historical memory of Ivan Groznyi is a very pragmatic question, did print change the accuracy of historiography? More has been written on the influence of the change from orality to writing on historical memory ${ }^{77}$ than on the transition from writing to print. Jacques le Goff referred to the "decisive advances by written memory connected with printing and literacy." $\mathrm{He}$ also observed that "Printing revolutionized Western memory, but slowly," although its full impact was not manifest until the eighteenth century ${ }^{78}$. Elizabeth Eisenstein, who is more concerned with the effect of printing on history than on historiography, concedes that printing spread inaccurate as well as accurate information, scientific and as well as esoteric occult works ${ }^{79}$.

${ }^{74}$ Al'shits D. N. Drevnerusskaia povest' pro tsaria Ivana Vasil'evicha i kuptsa Kharitona Beloulina... P.263.

75 Boeck B. J. Miscellanea Attributed to Kurbskii: the $17^{\text {th }}$ Century in Russia Was More Creative Than We Like to Admit // Kritika. 2012. Vol. 13, issue 4. P.955-963.

76 Ong W. J. Orality and Literacy: The Technologizing of the Word, with additional chapters by John Harley. London, 2012. P. 168-169.

77 For example: Sakellariou M. V. Between Memory and Oblivion: the transmission of early Greek historical traditions. Paris, 1990; Athens: Research Center for Greek and Roman Antiquity, National Hellenic Research Foundation, 1990.

78 le Goff J.History and Memory. Tr. Steven Randall and Elizabeth Claman. New York, 1992. P. 54, $81-90$.

9 Eisenstein E. L. The Printing Revolution in Early Modern Europe. Cambridge, 1983, P. 46. 
Although historians of history and memory use varying terminologies ${ }^{80}$, we need pause here to mention only one conception. Jeffrey Barash distinguishes between collective memory, which extends only to the temporal horizon of an individual's living memory, how far back a generation can remember, approximately three generations, from the historical past, which lies beyond that ${ }^{81}$. By his definition, I am dealing with both collective memory and the historical past.

I have tentatively formulated the following five observation:

First, the transition to print was a process, not a rapid "revolutionary" change. In the sixteenth century Tudor and Stuart historians still used manuscripts, not just printed material, although it was far easier to accumulate previous printed books and chronicles than if they, too, had remained only in manuscript. Historians too lazy to do archival research could commit historical gaffes in printed books as great as any manuscript historian had ever done. Sir Walter Ralegh got the date of Henry VII's death wrong ${ }^{82}$.

Second, while print fixed historical writing more permanently and permitted far wider distribution of books, it was no guarantee of accuracy either of text or fact. Typographical errors replaced scribal errors. Accuracy of fact remained as problematic ${ }^{83}$. Historians misread and misinterpreted facts just as before. Patrick Collinson points out that newspapers during the Elizabethan and early Stuart period reported "facts" that were fictitious about monsters, wonders, murders, wars, discoveries, and celebrities. Historians presented the story of mythical King Arthur as if it were true, and William Camden had no doubts that Brutus was the father of the English nation ${ }^{84}$. Although F. Smith Fussner eschewed testing the factual accuracy of the Tudor and Stuart historians whose publications he analyzed, he noted the powerful deleterious influence of censorship, via licensing and just arresting printers who published "offensive" authors, on historical truth. Historians such as Edward Herbert, Lord Herbert of Cherbury who imitated Thucydides and Tacitus by putting invented speeches into the mouths of historical personages, merely duplicated in print a practice of early modern Muscovite authors and compilers of narrative texts in manuscripts who had not read the Classics. John Stow, a historian of London, made factual mistakes, but admitted and corrected them. Camden in his history of the reign of Elizabeth I did not invent sources or speeches and tried to be objective, labeling, as Muscovite authors did, rumors as such when he reported them. He committed errors because he was denied access to archival evidence. On the other hand, Sir Francis Bacon was simply too lazy and arrogant to do archival research, resulting in enormous factual inaccuracies in his history of Henry VII. He misread Latin texts and invented speeches. Even the empirical John Selder in his history of tithes made some surprising and avoidable mistakes. These examples illustrate the impossibility of generalizing about "Tudor-Stuart historiography"; historiography in any finite time and specific place is unlikely to be homogeneous ${ }^{85}$.

${ }^{80}$ Cubitt G. History and Memory. Manchester, 2007.

${ }^{81}$ Barash J. A. Collective Memory and the Historian Past. Chicago, 2016.

82 Fussner F. S. The Historical Revolution. English Historical Writing and Thought 1580-1640. London, 1962. P. 267-274.

${ }^{83}$ G. Cubitt asserts that printing introduced "new concepts of accuracy" (Cubitt G. History and Memory. P. 190).

${ }^{84}$ Collinson P. Through Several Glasses Darkly: Historical and Sectarian Perceptions of the Tudor Church // Tudorism. Historical Imagination and the Appropriation of the Sixteenth Century / eds Tatiana C. String and Marcus Bull. Oxford, 2011. P.97-114.

${ }^{85}$ Fussner F. S. The Historical Revolution... P.XXI, 37-41, 158-160, 222, 230-252, 264-274, 297. 
Third, bias - in the case of Tudor-Stuart historiography, both dynastic and religious dominated interpretations even in relatively accurate histories ${ }^{86}$. However, whether Henry VIII was Anti-Christ or Elizabeth I was Jezebel are matters of interpretation, which do not necessarily relate to their factual bases.

Fourth, printing did nothing to eliminate ancient myths and legends in historiography. Indeed, printing facilitated the wider spread of such fantastic stories and historical mythology ${ }^{87}$. Tudor and Stuart historians did not question legends of St. George, King Arthur, or King Alfred, who supposedly founded Cambridge University ${ }^{88}$. Early modern authors sometimes doubted miracles, but wrote narratives replete with providential signs, tall tales, and exemplary behavior (for example, the ability to withstand torture), which strain the credulity of modern readers, not to mention invented or deliberate falsifications ${ }^{89}$.

However, fifth, although printing could generate myths and legends about more recent rulers, which changed with political circumstances, but at a higher level, that of reputation ${ }^{90}$, it is possible that printed histories avoided the most fantastic myths and legends about more recent history. In Tudor and Stuart historiography I have found only one story that matches the degree of "imagination" of numerous presentations of episodes in Ivan's life. Supposedly Mary Stuart's posthumous revenge was that Elizabeth I's body, lying in state in Whitehall, literally exploded, destroying her coffin, which English Catholics thought not only just, but entirely credible ${ }^{91}$. Notwithstanding this somewhat gruesome case, print historiography had no problem dealing with benign fables, such as those about George Washington popularized by Parson Weems ${ }^{92}$. Abraham Lincoln's apocryphal wisdom is often equally fictitious. Rumor had no difficulty finding its way into print, in gossip columns and political rags, and nowadays finds its first outlet not orally but on the internet.

The differences between the inaccuracies in Muscovite manuscript historical memory of Ivan compared to print historical memory in early modern Europe may be qualitative, not quantitative, in the type of falsified narrative and "fact" propagated, or this distinction could be overturned by more extensive familiarity with early modern English historiography. Before we can properly assess the consequences of the absence of print technology on Muscovite historical memory of Ivan Groznyi, we need to know more of the consequences of the presence of print technology on early modern European historiography. The virtual absence of print technology in Muscovy might very well not be the cause of ignorance of

86 Collinson P. Through Several Glasses Darkly...; String T. C. Myth and Memory in Representations of Henry VIII, 1509-2009 // Tudorism. Historical Imagination and the Appropriation of the Sixteenth Century. Eds Tatiana C. String and Marcus Bull. Oxford, 2011. P.201-222; Walker G. "A Great Guy with his Chopper": The Sex Life of Henry VIII on Screen and in the Flesh // Ibid. P. 223-242; Jackson C. Lord Herbert of Cherbury and the Presentation of the Henrician Reformation in his Life and Reign of King Henry the Eighth // Seventeenth Century. 2013. Vol. 18, issue 2. P.139-161; Collinson P. This England. Essays on the English Nation and commonwealth in the sixteenth century. Manchester, 2011. P. 143-166, 245-308.

87 Filyushkin A. Why Did Muscovy Not Participate in the "Communication Revolution" in the Sixteenth Century? Causes and Effects // Canadian-American Slavic Studies. 2017. Vol.51, issue 2-3. P. 343.

${ }^{88}$ Cubitt G. History and Memory... P. 206.

${ }^{89}$ Collinson P. This England... P. 216-244.

90 Thompson V.E. The Creation, Destruction and Recreation of Henry IV: Seeing Popular Sovereignty in the Statue of the King // History \& Memory. 2012. Vol. 24, issue2. P. 5-40.

${ }_{91}$ Collinson P. This England... P. 151.

92 Cubitt G. History and Memory... P. 206. 
the reign of Ivan Groznyi in Muscovite historical memory. Historical memory is always selective, and errors of omission are just as erroneous as errors of commission. Modern historiography partakes of this syndrome ${ }^{93}$.

Whatever the explanation of these flaws in Muscovite historical memory, the presence of disinformation and misinformation about Ivan continues to influence modern Russian historiography not only because so much erroneous information is accepted by far too many historians, but because it feeds the powerful negative image of Ivan in the audience of scholarly studies, and thus exacerbates the problem of separating the man from the myth, which is still the goal of professional scholarship.

\section{References}

Al'shits D. N. Drevnerusskaia povest' pro tsaria Ivana Vasilevicha i kuptsa Kharitona Beloulina. Trudy otdela drevnerusskoi literatury, 1961, vol. 17, pp. 255-271. (In Russian)

Avtokratov V.N. "Rech' Ivana Groznogo" kak politicheskii pamflet kontsa XVII veka. Trudy otdela drevnerusskoi literatury, 1955, vol. 11, pp. 255-279. (In Russian)

Barash J. A. Collective Memory and the Historian Past. Chicago, University of Chicago Press, 2016, 286 p.

Boeck B. J. Miscellanea Attributed to Kurbskii. The $17^{\text {th }}$ Century in Russia Was More Creative Than We Like to Admit. Kritika, 2012b, vol. 13, issue 4, pp. 955-963.

Boeck B. J. The Don Interpolation: An Imagined Turning Point in Russian Relations with the Tatar World. Dubitando. Studies in History and Culture in Honor of Donald Ostrowski. Eds Brian Boeck, Russell E. Martin and Daniel B. Rowland. Bloomington, Slavica Publishers, Inc, 2012a, pp. 129-138.

Bushkovitch P. Possevino and the Death of Tsarevich Ivan Ivanovich. Cahiers du monde russe, 2014, vol. 55, issue 1-2, pp. 119-134.

Collinson P. This England. Essays on the English Nation and commonwealth in the sixteenth century. Manchester, Manchester University Press, 2011a, 316 p.

Collinson P. Through Several Glasses Darkly: Historical and Sectarian Perceptions of the Tudor Church. Tudorism. Historical Imagination and the Appropriation of the Sixteenth Century. Eds Tatiana C. String and Marcus Bull. Oxford, Oxford University Press, 2011b, pp. 97-114.

Cubitt G. History and Memory. Manchester, Manchester University Press, 2007, 263 p.

Eisenstein E. L. The Printing Revolution in Early Modern Europe. Cambridge, Cambridge University Press, $1983,297 \mathrm{p}$.

Filiushkin A. I. Istoriia odnoi mistifikatsii. Ivan Groznyi i "Izbrannaia Rada". Moscow, Voronezh State University Press, 1998, 352 p. (In Russian)

Filjushkin A. The Mystery of a Political Masquerade (Concerning the Article of Donald Ostrowski). Russian History, 2012, vol. 39, issue 3, pp. 301-305.

Filyushkin A. Why Did Muscovy Not Participate in the "Communication Revolution" in the Sixteenth Century? Causes and Effects. Canadian-American Slavic Studies, 2017, vol. 51, issue 2-3, pp. 339-350.

Fussner F. S. The Historical Revolution. English Historical Writing and Thought 1580-1640. London, Rutledge and Kegan Paul, 1962, 343 p.

Grekov I. B. Ob ideino-politicheskikh tendentsiiakh nekotorykh literaturnykh pamiatnikov nachala XVII v. (ob avtore Piskarevskogo letopistsa). Kul'turnye sviazi narodov Vostochnoi Evropy v XVI v. Problemy vzaimootnoshenii Pol'shi, Rossii, Ukrainy, Belorusii i Litvy v epokhu Vozrozhdeniia. Moscow, Nauka Publ., 1976, pp. 329-358. (In Russian)

Halperin C. J. Did Ivan IV's Oprichniki Carry Dogs' Heads on Their Horses? Canadian-American Slavic Studies, 2012a, vol. 46, issue 1, pp. 40-67.

Halperin C.J. Ivan IV and Chinggis Khan. Jahrbücher für Geschichte Osteuropas, 2003, vol. 51, issue 4, pp. 481-497.

Halperin C. J. Ivan IV as Autocrat (samoderzhets). Cahiers du monde russe, 2014a, vol. 55, issue 3/4, pp. 197213.

Halperin C. J. Metropolitan Makarii and Muscovite Court Politics during the Reign of Ivan IV. Russian Review, 2014b, vol. 763, issue 3, pp. 447-464.

${ }^{93}$ Halperin C.J. Omissions of National Memory: Russian Historiography on the Golden Horde as

Politics of Inclusion and Exclusion // Ab Imperio. 2004. Issue 3. P. 131-144. 
Halperin C. J. Omissions of National Memory: Russian Historiography on the Golden Horde as Politics of Inclusion and Exclusion. Ab Imperio, 2004, iss. 3, pp. 131-144.

Halperin C.J.Russia Between East and West: Diplomatic Reports During the Reign of Ivan IV.Saluting Aaron Gurevich: Essays in History, Literature and Other Subjects. Eds Yelena Mazour-Matusevich and Alexandra S. Korros. Leiden, Koninklijke Brill NV, 2010, pp. 81-103.

Halperin C. J. The Defeat and Death of Batu. Russian history, 1983, issue 10, pp. 50-65.

Halperin C. J. The Metamorphosis of Ivan IV into Ivan the Terrible. Miscellanea Slavica. Sbornik statei $k$ 70-letiiu Borisa Andreevicha Uspenskogo. Ed. by F. B. Uspenskii. Moscow, Indrik Publ., 2008, pp. 379397.

Halperin C. J. Simeon Bekbulatovich and the Mongol Influence on Ivan IV's Muscovy. Russian History, 2012b, vol. 39, issue 3, pp. 306-330.

Jackson C. Lord Herbert of Cherbury and the Presentation of the Henrician Reformation in his Life and Raigne of King Henry the Eighth. Seventeenth Century, 2013, vol. 18, issue 2, pp. 139-161.

Kagan M.D. Legendarnaia perepiska Ivana IV s turetskim sultanom kak literaturnyi pamiatnik pervoi chetverti XVII v. Trudy otdela drevnerusskoi literatury, 1957, vol. 13, pp. 246-272. (In Russian)

Karamzin N. M. Istoriia gosudarstva Rossiiskago, v. 9. St. Petersburg, Izdanie Evg. Evdokimova Publ., 1892, 471 p. (In Russian)

Kazanskaia istoriia. Ed. by G. N. Moiseeva. Moscow;Leningrad, AN SSSR Publ., 1954, 191 p. (In Russian)

Keenan E. L. Who Was 'Ivan Timofeev'?" Harvard Ukrainian Studies, 2011-2014, vol. 32/33, pp. 415-423.

Khazanova S. I. Oprichnina v Piskarevskom letopiste i letopisanie XVII veka. Arkhiv russkoi istorii, 2007, vol. 8, pp. 49-59. (In Russian)

Khazanova S. I. Piskarevskii letopisets: Proiskhozhdenie, Istochniki, Avtorstvo. Moscow, Kvadriga Publ., 2014, 170 p. (In Russian)

Kolobkov V.A.Mitropolit Filipp i stanovlenie moskovskogo samoderzhaviia, Oprichnina Ivana Groznogo. St. Petersburg, Ateleiia Publ., 2004, 639 p. (In Russian)

Kuznetsov I.I.Sviatye blazhennye Vasilii i Ioann, Khrista radi moskovskie chiudotvortsy. Zapiski Moskovskogo arkheologicheskago instituta, 1910, vol. 8, 494, IV, 4 p. (In Russian)

Le Goff J.History and Memory. Transl. Steven Randall and Elizabeth Claman. New York, Columbia University Press, 1992, 265 p.

Lobakova I. A.Zhitie mitropolita Filippa. Issledovanie i tektsy. St. Petersburg, Dmitrii Bulanin Publ., 2006, 306 p. (In Russian)

Lyzlov A.Skifskaia istoriia. Eds E. V. Chistiakova and A. P. Bogdanov. Moscow, Nauka Publ., 1990, 518 p. (In Russian)

Martin J.Simeon Bekbulatovich and Steppe Politics: Some Thoughts on Donald Ostrowski's Interpretation of the Tsar's Remarkable Career. Russian History, 2012, vol. 39, issue 3, pp. 331-338.

Martin R.E.A Bride for the Tsar: Bride-Shows and Marriage Politics in Early Modern Russia. DeKalb, Northern Illinois University Press, 2012, XIV, 480 p.

Morozov S. A. K izucheniiu istochnikov Postnikovskogo i Piskarevskogo letopistsev. Letopisi i khroniki 1984. Moscow, Nauka Publ., pp. 59-74. (In Russian)

Ong W. J. Orality and Literacy: The Technologizing of the Word. With additional chapters by John Harley. London, Routledge Publ., 2012, 232 p.

Ostrowski D. Simeon Bekbulatovich's Remarkable Career as Tatar Khan, Grand Prince of All Rus', and Monastic Elder. Russian History, 2012, vol. 39, issue 3, pp. 269-299, 339-345.

Poe M. What Did Russians Mean When They Called Themselves 'Slaves of the Tsar'? Slavic Review, 1998, vol. 57, issue 3, pp. 585-608.

Prince A. M.Kurbsky's History of Ivan IV.Ed. by J.L.I. Fennell. Cambridge, Cambridge University Press, 1965, 314 p.

Rock S. Popular Religion in Russia. 'Double Belief' and the making of an academic myth. London, Routledge Publ., 2007, 234 p.

Skrynnikov R. S. Tsarstvo terrora. St. Petersburg, Nauka Publ., 1992, 573 p. (In Russian)

Sakellariou M. V. Between Memory and Oblivion: the transmission of early Greek historical traditions. Paris; Athens, Diffusion de Bocard; Research Center for Greek and Roman Antiquity, National Hellenic Research Foundation, 1990, 267 p.

Solodkin Ia. G. Po povodu atributsii Piskarevskogo letopistsa. Trudy otdela drevnerusskoi literatury, 1990, vol. 44, pp. 387-396. (In Russian)

String T. C. Myth and Memory in Representations of Henry VIII, 1509-2009. Tudorism. Historical Imagination and the Appropriation of the Sixteenth Century. Eds Tatiana C. String and Marcus Bull. Oxford, Oxford University Press, 2011, pp. 201-222. 
Swoboda M. The Place of Novgorod in Ivan Timofeyev's Vremennik. Russian History, 1998, vol. 25, issue 4, pp. 409-428.

Thompson V.E. The Creation, Destruction and Recreation of Henry IV: Seeing Popular Sovereignty in the Statue of the King. History \& Memory, 2012, vol. 24, issue 2, pp. 5-40.

Tikhomirov M. N. Kratkie zametki o letopisnykh proizvedeniiakh v rukupisnykh sobraniiakh Moskvy. Moscow, AN USSR Publ., 1962, 184 p. (In Russian)

Tikhomirov M.N.Piskarevskii letopisets kak istoricheskii istochnik o sobytiiakh XV - nachala XVII v. Russkoe letopisanie. Moscow, Nauka Publ., 1979, pp. 232-247. (In Russian)

Walker G. "A Great Guy with his Chopper": The Sex Life of Henry VIII on Screen and in the Flesh. Tudorism. Historical Imagination and the Appropriation of the Sixteenth Century. Eds Tatiana C. String and Marcus Bull. Oxford, Oxford University Press, 2011, pp. 223-242.

Waugh D.C. The Great Turkes Defiance. On the History of the Apocryphal Correspondence of the Ottoman Sultan in its Muscovite and Russian Variants. Columbus, Slavica Press Inc., 1978, 355 p.

Zguta R.Russian Minstrels. A History of the Skomorokhi. Philadelphia, University of Pennsylvania Press, $1978,160 \mathrm{p}$.

Received: 26.07.2017

Accepted: 28.12.2017 